\title{
Studying Self-Efficacy Among Teachers in Poland Is Important: Polish Adaptation of the Teacher Efficacy for Inclusive Practice (TEIP) Scale
}

\author{
Zuzanna Narkun \\ The Maria Grzegorzewska University \\ Joanna Smogorzewska \\ University of Warsaw
}

\begin{abstract}
The main aim of the study was to adapt into Polish the Teacher Efficacy for Inclusive Practice (TEIP) Scale, originally prepared by Sharma, Loreman, and Forlin (2011). A total of 291 Polish teachers participated in the study. We conducted a factor analysis and reliability analysis and obtained satisfactory results similar to those of the authors of the scale. We also conducted a correlation analysis of selfefficacy and attitudes toward inclusive education. The correlation between the entire scale and the attitudes was non-significant. However, there was a significant relationship between efficacy in collaboration and attitudes toward inclusion, which is in line with other research. Although our results are similar to previously published results, more research on this topic is needed.
\end{abstract}

The Salamanca Statement (UNESCO, 1994) provides a right to education in mainstream school for all students, including those with different kinds of disabilities and learning difficulties. Thanks to this document and other legislative acts, implementing inclusive education is possible and currently is a priority for educational policy all over the world (Ainscow \& César, 2006). Schools that implement ideas of inclusion try to be welcoming and effective and accept all students regardless of differences between them (Kinsella \& Senior, 2008). In inclusive classrooms, children with and without special educational needs learn together. Teaching in such classrooms is a challenge for teachers who do not always feel prepared to work with students with disabilities (Forlin, 2010). In the process 
of teaching in inclusive education, not only is knowledge important, but also the teacher's personal beliefs that he or she is able to carry through teaching in the classroom with students with diverse learning needs (Klassen, Tze, Betts, \& Gordon, 2011). Teachers' beliefs in this case can be labeled as self-efficacy in inclusive education.

In present day, the issue of self-efficacy is often undertaken by international researchers (Savolainen, Engelbrecht, Nel, \& Malinen, 2012), but there are very few analyses on this topic in Poland. Moreover, Poland is still in the process of educational changes, and gaining new knowledge about determinants favouring inclusive education is highly needed. That is why we decided to prepare a Polish adaptation of the Teacher Efficacy for Inclusive Practice (TEIP) scale, originally prepared by Sharma, Loreman, and Forlin (2011). The original scale has been used by researchers such as Malinen, Savolainen, and $\mathrm{Xu}$ (2012) and Yada and Savolainen (2017), and it has shown good psychometric properties. In the present text, we analyze the relationship between teachers' self-efficacy in inclusive education and their attitudes toward this form of education.

\section{Inclusive Education in Poland}

Even though Poland does not have long tradition of inclusive education, and its development was only possible after political changes in 1989, when democracy started, recently Poland has given a lot of attention to implement this idea into educational practice (Chrzanowska, 2015).

The Education System Act from 1991, which regulates the education system in Poland, warrants all students, including those with different kinds of disabilities, access to mainstream schools. However, in this act inclusive education is not mentioned. Only the Regulation of the Minister of National Education of the 9th of August (2017) "on the conditions for the provision of education and care to children and young people who are disabled, socially maladjusted or at risk of social maladjustment" mentions that education of children with special educational needs should be organized in an inclusive environment, close to children's homes.

In Poland there are three environmental settings in which students with disabilities can learn: special, integrative, and mainstream schools and classrooms. In Poland it is solely the parents' decision in what type of school the child is going to learn. Classes in integrative schools have a reduced number of students (up to 15 students without disabilities, 3-5 students with disabilities) and two teachers: a general education teacher and a special education teacher. In mainstream (inclusive) schools, there are approximately 25 students in the classroom (including 1-2 students with disabilities), and the special education teachers work in such classrooms only when a student with a disability has autism spectrum disorder or multiple disabilities. The special education teacher needs to have a diploma in special education; a general education teacher, however, is not required to be formally prepared for working with children with special educational needs (SEN), but can teach children with SEN. In the case of teacher's support, the integrative schools are probably easier to work in, but in the case of the natural environment for students, inclusive classrooms are more beneficial. 
Statistics show that from 1991 to 2007 the number of special education students learning in special schools had decreased by 50\% (Central Statistical Office, 2007). In recent decades, however, taking into account demographic changes, the number of students with disabilities, learning in inclusive settings (integrative and mainstream classes), is rather stable. Approximately $40 \%$ of students with disabilities still learn in special schools (Chrzanowska, 2015).

In the current article we define inclusive education in accordance with Polish educational acts, i.e., inclusive education means a common learning process for children with and without disabilities in a mainstream classroom. This definition is connected to the fact that Poland is still rather a mono-cultural country. However, children from different cultures, living in Poland, also learn in general education classrooms. Students with different disabilities can learn in one integrative or mainstream classroom. In Polish law there are no regulations concerning this issue. However, in most cases, students with mild disabilities, mostly with mild intellectual disabilities and Asperger syndrome, learn in mainstream classrooms.

\section{Teachers' Self-Efficacy}

The construct of self-efficacy originates from Bandura's social learning theory, which assumes that people learn through observations (Bandura, 1971). Self-efficacy concerns personal beliefs about the ability to do something (Bandura, 1977). The sense of selfefficacy affects emotions, thoughts, and behaviours. Guskey and Passaro (1994) defined the sense of self-efficacy of a teacher as the teacher's belief in how much he or she can influence the school achievement of students with and without learning difficulties.

The sense of self-efficacy depends on four factors: mastery experiences, vicarious experiences, verbal persuasion, and emotional arousal. According to Bandura, the factor concerning personal experience is most important for self-efficacy (Bandura, 1977). However, in the case of teachers who have just started their careers and do not have much educational experience, other factors are more important in forming the sense of self-efficacy. It is worth mentioning that the sense of self-efficacy among teachers with significant work experience is rather stable, whereas among young teachers it is prone to change, especially in the first year of work (Ross \& Bruce, 2007; Woolfolk Hoy \& Burke Spero, 2005).

The sense of self-efficacy is not a general feature of a person but rather specific to different areas of functioning (Bandura, 1977). A person can feel a high sense of selfefficacy while learning foreign languages, but at the same time, he or she can have a low sense of self-efficacy in establishing relationships with other people. The problem is similar in the case of teachers. Teachers' sense of self-efficacy differs depending on student group, school subject, or other variables related to the environment or the kinds of schools in which they work (Tschannen-Moran \& Woolfolk Hoy, 2007).

Research has shown that teachers with a high sense of general teaching efficacy are more eager to raise their qualifications (Coladarci, 1992), are more open to novel and differentiated actions in their workplace (Cousins \& Walker, 2000; De Neve, Devos \& Tuytens, 2015), and show more engagement in contact with other employees and 
students' parents (Hoover-Dempsey, Bassler, \& Brissie, 1987). Moreover, teachers with a high sense of self-efficacy have lower levels of work stress than others (Skaalvik \& Skaalvik, 2007, 2010). The high sense of self-efficacy is also positively correlated with work satisfaction of teachers as well as students' academic achievement (Caprara, Barbaranelli, Steca, \& Malone, 2006; Guo, Piasta, Justice, \& Kaderavek, 2010; Herman, Hickmon-Rosa, \& Reinke, 2018).

The sense of self-efficacy for teachers has a cyclical nature. Teachers with a high sense of self-efficacy are more engaged in a didactic process. As a result, their students have better academic achievement, which in turn causes a better sense of success in the teachers. Thus, teachers gather positive experiences in performing personal tasks. This, in turn, reinforces their already high sense of self-efficacy, which is not without impact on their students (Tschannen-Moran, Woolfolk Hoy, \& Hoy, 1998).

\section{The Sense of Self-Efficacy of Teachers in Inclusive Education}

The sense of self-efficacy for teachers in inclusive education can be defined as beliefs concerning the ability to teach a diverse group of students learning in the same classroom and the ability to co-operate with other educators, specialists, and parents (Malinen, 2013). A teacher with a low sense of self-efficacy in inclusive education will think that he or she does not have the resources to effectively teach students with and without disabilities. A teacher with a high sense of self-efficacy in inclusive education will think of himself or herself as able to undertake and realize inclusive education in practice. However, the sense of self-efficacy does not necessarily mean achieving success in practice (Sharma et al., 2011).

Research conducted so far with the TEIP Scale (Sharma et al., 2011) on culturally diverse populations has shown a positive correlation between teachers' sense of selfefficacy in inclusive education and their attitudes toward inclusive education (Malinen et al., 2012; Savolainen et al., 2012; Yada \& Savolainen, 2017). Savolainen et al. (2012), while conducting comparative research among teachers from South Africa and Finland, showed that the sense of self-efficacy in inclusive education and attitudes toward inclusion are correlated, most strongly in the subscale of self-efficacy in collaboration with other teachers, specialists, and parents. This relationship was reaffirmed in a study by Malinen et al. (2012) conducted with a group of teachers from Beijing. The results showed that the sense of self-efficacy in collaboration was the only predictor of attitudes. Yada and Savolainen (2017) stated that although Japanese teachers generally showed positive attitudes toward inclusion and low self-efficacy, it is possible to observe a positive relationship between those variables.

\section{Teachers' Attitudes Toward Inclusive Education}

Attitudes are tendencies of a person to positively or negatively assess a subject (Ajzen, 2001). Teachers' attitudes toward inclusive education of students with special educational needs is one factor responsible for effective inclusive education implementation (Meijer, 2003; Moberg, Muta, Korenaga, Kuorelahti \& Savolainen, 2019). Research on teachers' attitudes toward common learning of children with and without disabilities shows that in most cases, teachers display positive attitudes toward 
the general philosophy of inclusion, but at the same time, they have concerns about implementing this philosophy in practice (Avramidis \& Norwich, 2002). However, De Boer, Pijl, and Minnaert (2011) stated in their review that teachers' attitudes toward inclusion were negative or, at best, neutral. This discrepancy probably stems from the fact that, according to teachers, they do not have the necessary preparation to work with students with disabilities, they do not have enough support from professionals, and the schools are not ready to enrol students with special educational needs (Avramidis \& Norwich, 2002; Klingner, Ahwee, Pilionieta, \& Menedez, 2003).

Variables that correlate with attitudes can be categorized into three main groups: those related to the teacher, those related to the student, and those related to the school environment. The first and largest group consists of factors such as teaching experience, preparation for special education, experience working with people with disabilities, and self-efficacy (Avramidis \& Norwich, 2002). Teachers with more work experience and without preparation in special education are less favourable to inclusion of students with special educational needs than those with less experience. Experience working with students with disabilities can influence attitudes in two ways. On one hand, the contact hypothesis states that different experiences can foster positive attitudes (Avramidis, Bayliss, \& Burden, 2000; Moberg et al., 2019). On the other hand, contact with students with disabilities can be so stressful that it can negatively influence attitudes toward inclusion (Forlin, 1995). The sense of self-efficacy in previous research was positively correlated with attitudes toward inclusion (Savolainen et al., 2012; Weisel \& Dror, 2006). Factors relating to the students include the nature of their disability. Teachers are more often favourable to teaching students with mild sensory or physical disabilities in contrast to students with severe emotional and behavioural disorders or difficulties with learning. The school environment will have a positive influence on the attitudes of teachers through professional support (i.e., providing teachers special tools or opportunities to consult with specialists). It is important to start implementing changes in schools even before students with special needs enrol there (Avramidis \& Norwich, 2002).

\section{Original Version of the TEIP Scale}

Because the sense of self-efficacy is a context-specific notion, tools for its assessment should be prepared with consideration for the specific circumstances of teaching (Klassen et al., 2011). Previously, researchers prepared scales for assessing a general sense of self-efficacy among teachers with the Teacher Efficacy Scale (Gibson \& Dembo, 1984) as well as scales assessing efficacy in specific subjects such as the Science Teaching Efficacy Belief Instrument (Riggs \& Enochs, 1990). Sharma et al. (2011), however, prepared a tool for the assessment of teachers' self-efficacy in inclusive education. The main aim of the authors' work was to prepare a measure for classroom situations in which students with diverse needs and abilities or disabilities learn together.

Based on an analysis of the literature on inclusive education, as well as taking previous tools assessing the sense of self-efficacy among teachers as examples, Sharma et al. prepared 35 statements concerning three areas related to teachers' abilities: knowledge in the area of education, the ability to manage the classroom, and the ability to co-operate with other teachers and parents. For assessing the statements, a 6-point Likert scale was 
used (from strongly disagree to strongly agree). After consultation with other researchers knowledgeable in inclusion, six statements were deleted from the scale, and a few others were modified. In the first study, 609 people who studied to become teachers from four countries (Canada, Australia, Hong-Kong, and India) participated (Sharma et al., 2011).

Using statistical analyses, items that had high indexes of correlation or those that loaded more than one factor were deleted from the scale. As a result, the final version of the scale consists of 18 statements. A factor analysis of the scale revealed its multidimensional structure and distinguished the following three factors, each with 6 statements: Efficacy in Using Inclusive Instruction, Efficacy in Collaboration, and Efficacy in Managing Behaviours. The first factor explained $25.5 \%$ of the overall variance, and the reliability of this subscale was Cronbach's $\alpha=0.93$. The second factor explained $19.8 \%$ of the variance, and its reliability was $\alpha=0.85$. The third factor explained $19.0 \%$ of the variance, and its reliability was $\alpha=0.85$.

The TEIP scale has been translated to Mandarin and was used in the study by Malinen et al. (2012) with a group of teachers from Beijing. In this sample, the scale reproduced its three-factor structure and showed a reliability of $\alpha=0.91$. The TEIP scale was also used with Japanese teachers. The analysis reaffirmed the three subscales in the tool and showed high reliability ( $\alpha=0.93$; Yada \& Savolainen, 2017).

Research conducted with the TEIP in different countries and cultures makes it possible to adapt the scale to Polish and to prepare the needed analyses. Results gathered from Polish teachers can enrich existing knowledge about teachers' self-efficacy in different regions of the world.

\section{The Present Study}

In the present study, our aims were twofold. First, we wanted to examine the psychometric properties of the TEIP scale with a population of Polish teachers and compare those properties to previous results. Thus, we prepared a factor analysis with statements translated to Polish, we calculated descriptive statistics for the scale, and we checked the reliability of the scale. Our second main aim was to observe whether there is a statistically significant relationship between teachers' sense of self-efficacy and their attitudes toward inclusive education. Thus, we conducted correlation analyses as well as a series of regression analyses.

\section{Method}

\section{Participants}

A total of 291 teachers from eight primary schools in different regions of Poland participated in the study. It was a random sample; filling in the questionnaires was not mandatory, thus only about $50 \%$ of teachers who were invited to participate agreed to take part in the study. Teachers were asked to fill in two paper-pencil questionnaires and to answer a few demographic questions. Most of the participants $(n=251,86.3 \%)$ were women. The mean work experience among the participants was $M=14$ years $(S D=9.72)$. Over one-third of the teachers worked in K-3 classrooms $(n=101,34.7 \%)$, and special education teachers were excluded from the analysis. Most teachers taking part 
in the study declared that they had experience working with children with different kinds of disabilities $(n=215,73.9 \%)$. Among these teachers, most of them currently had a student with a disability in their classroom $(n=186,63.9 \%)$. The largest group of teachers had experience in working with students with autism spectrum disorders $(n=159,54.6 \%)$, students with mild intellectual disabilities $(n=117,40.2 \%)$, and students with emotional and behavioural disorders $(n=108,37.1 \%)$. Fewer teachers worked with students with physical disabilities $(n=71,24.4 \%)$, students with hearing impairments $(n=63,21,6 \%)$, or students with visual impairments $(n=45,15.5 \%)$. Almost all of the participants held a master's degree in education $(n=213,93.4 \%)$. Most of the teachers worked in Polish cities $(n=256,88 \%)$.

\section{Measures}

The first measure was the Teacher Efficacy for Inclusive Practice (TEIP) scale, originally prepared by Sharma et al. (2011). The scale consists of 18 statements assessed with a 6-point Likert scale, and three subscales: Efficacy in Using Inclusive Instructions ("I am confident when dealing with students who are physically aggressive"), Efficacy in Collaboration ("I can assist families in helping their children do well in school"), and Efficacy in Managing Behaviour ("I am able to provide an alternate explanation or example when students are confused"). Overall, the original scale has high reliability $(\alpha=0.89)$. In the whole scale and in subscales, there can be a minimum score of 1 and a maximum score of 6 (the sum of all statements in the scale or subscale divided by the number of statements in the scale or subscale). Higher scores indicate higher self-efficacy.

To assess teachers' attitudes toward inclusive education, we used the scale Measuring Attitudes Toward Mainstreaming, originally prepared by Chow and Winzer (1992). This is the only scale for measuring attitudes that has been adapted into Polish; thus, despite its imperfect psychometric values, we decided to use it in our study (Kossewska \& Pilecka, 2000). The questionnaire consists of 20 statements, which are assessed on a 5-point Likert scale. The measure has two subscales related to positive (i.e., "Mainstreaming the exceptional child will promote his/her independence") and negative ("The contact which regular students have with mainstreamed exceptional students may be harmful to the regular students") aspects of inclusion of students with disabilities. The Polish version of the measure has good reliability, Cronbach's $\alpha=0.73$ (Kossewska, 2000). To make the results clearer and easier to interpret, in the analysis we recoded the scale with questions about negative aspects of inclusion and summed the results from both scales. Higher scores indicate more positive attitudes toward inclusion.

Additionally, teachers were asked to answer demographic questions such as experience working with students with disabilities, subjective preparation for working with students with disabilities, school subjects they taught, their education level, and their place of living. 


\section{Procedure}

The content of the TEIP scale was translated to Polish with back-translation. Bilingual researchers who are knowledgeable in inclusive education were consulted about the Polish wording.

We used the original number of statements with the same order as well as the same categories of answers (Likert scale from $1=$ strongly disagree to $6=$ strongly agree).

The data were gathered from November 2017 until June 2018. The principal of each school agreed to take part in this research. Teachers were asked to fill out the questionnaires during professional meetings at their school. In total, 350 questionnaires were distributed among the teachers, and 295 questionnaires were returned. However, four of them were blank, so they were excluded.

The analyses consisted of a factor analysis, descriptive analysis of statements, reliability analysis, and correlations between the TEIP scale (Sharma et al., 2011) and Chow and Winzer's scale measuring attitudes toward mainstreaming (1992), which were run with IBM SPSS Statistics 24.

\section{Results}

\section{Psychometric Properties of the Polish Version of the TEIP Scale}

Factor analysis of the TEIP scale. To observe the internal structure of the TEIP scale, we used an exploratory factor analysis with principal component analysis. The factor analysis was justified by the KMO test value (0.923) as well as the result of Bartlett's test $(p<.0001)$. The results showed that the best solution was to extract three factors (three eigenvalues above 1) that together explained $65.05 \%$ of the overall variance of results. The first factor explained $46.61 \%$ of variance; the second factor, $10.57 \%$; and the third factor, $7.86 \%$ of variance. A three-factor solution is also in accordance with the original version of the scale.

For further analysis, we used an orthogonal rotation solution with Varimax rotation. After using this solution, we received factor loadings with values between 0.429 and 0.873 for items in each factor (see Table1).

In accordance with the authors of the scale (Sharma et al., 2011), we used the following labels for the subscales: Factor 1, Efficacy in Managing Behaviours; Factor 2, Efficacy in Collaboration; and Factor 3, Efficacy in Using Inclusive Instruction. Items loading individual factors are almost identical to the original version of the TEIP scale. The only difference was the third item, "I am confident in designing learning tasks so that the individual needs of students with disabilities are accommodated." The value of factor loading (0.564) shows that the statement should be included in Subscale 2 concerning efficacy in collaboration. However, the item had a similar (only slightly lower) loading for the third factor $(0.459)$. In the original version of the scale, this statement was included in the factor concerning efficacy in using inclusive instruction. Also, the meaning of this statement shows its natural affinity to the third factor. Thus, we decided to include the third item in Factor 3. At the same time, it is important to mention that in 
most cases, the loading values for individual items were slightly higher in the original version in comparison to the Polish version.

Table 1.

Results of the Rotated Factor Matrix.

\begin{tabular}{rccc}
\hline Item number & Factor $\mathbf{1}$ & Factor $\mathbf{2}$ & Factor $\mathbf{3}$ \\
\hline 8 & $\mathbf{0 . 8 7 3}$ & 0.178 & 0.196 \\
9 & $\mathbf{0 . 8 6 4}$ & 0.212 & 0.168 \\
10 & $\mathbf{0 . 8 2 1}$ & 0.181 & 0.278 \\
7 & $\mathbf{0 . 7 5 6}$ & 0.175 & 0.227 \\
11 & $\mathbf{0 . 7 2 3}$ & 0.290 & 0.193 \\
12 & $\mathbf{0 . 5 6 0}$ & 0.319 & 0.404 \\
17 & 0.167 & $\mathbf{0 . 8 5 5}$ & 0.106 \\
15 & 0.168 & $\mathbf{0 . 8 1 1}$ & 0.165 \\
14 & 0.188 & $\mathbf{0 . 7 9 6}$ & 0.182 \\
18 & 0.232 & $\mathbf{0 . 7 1 3}$ & 0.112 \\
16 & 0.319 & $\mathbf{0 . 6 3 9}$ & 0.247 \\
3 & & $\mathbf{0 . 5 6 4}$ & $\mathbf{0 . 4 5 9}$ \\
13 & 0.360 & $\mathbf{0 . 5 0 7}$ & 0.352 \\
2 & 0.157 & 0.147 & $\mathbf{0 . 8 0 7}$ \\
5 & 0.286 & 0.189 & $\mathbf{0 . 7 4 4}$ \\
1 & 0.171 & 0.178 & $\mathbf{0 . 7 1 6}$ \\
4 & 0.355 & 0.184 & $\mathbf{0 . 7 0 6}$ \\
6 & 0.393 & 0.288 & $\mathbf{0 . 4 2 9}$ \\
\hline
\end{tabular}

Note: Factor 1, Efficacy in Managing Behaviours; Factor 2, Efficacy in Collaboration; Factor 3, Efficacy in Using Inclusive Instruction.

Correlations between the general result in the scale and its detailed statements were satisfactory, with values $r=0.590-0.739(p<.0001)$. The correlations between the entire scale and subscales $(r=0.855-0.860, p<.0001)$ and between subscales $(r=0.573-$ $0.631, p<.0001)$ were high and significant.

The Polish teachers' overall self-efficacy for inclusive practice was rather high $(M=4.78 ; S D=0.60$ on the TEIP scale ranging from 1 to 6$)$. The Polish teachers' level of Self-efficacy in Using Inclusive Instruction was the highest of all three dimensions of the TEIP scale $(M=4.96 ; S D=0.64)$. The lowest level was Self-Efficacy in Collaboration $(M=4.62 ; S D=0.75)$, which can indicate that Polish teachers have some difficulties with team planning and designing the teaching process.

Reliability of the TEIP scale. Analyses of reliability of the TEIP scale and its subscales were run with Cronbach's $\alpha$ method of internal consistency based on correlation coefficients. The reliability for the entire scale was high $(\alpha=0.93)$. Also, each subscale had good reliability: 0.92 (Subscale 1), 0.88 (Subscale 2) and 0.83 (Subscale 3). 
The Polish version of the scale replicated the high internal consistency of the original version of TEIP scale (Sharma et al., 2011), which is in line with results obtained by other researchers (Malinen et al., 2012; Yada \& Savolainen, 2017).

\section{The Sense of Self-Efficacy in Inclusive Education and Attitudes Toward Inclusive Education of Students with Disabilities}

Descriptive statistics for attitudes toward inclusive education show that teachers in our sample had highly positive attitudes toward inclusion $(M=75.68 ; S D=8.73$; range 43-97). This result is similar to other results among Polish teachers working in inclusive settings ( $M=74.75 ; S D=8.25$; Szumski, 2010).

To observe the relationship between the sense of self-efficacy in inclusive education of teachers and their attitudes toward inclusive education, we checked for Pearson's $r$ correlations between variables. It turned out that the correlation between the overall sense of self-efficacy, measured with the TEIP scale (Sharma et al., 2011), and attitudes toward inclusive education, measured with Chow and Winzer's questionnaire (1992), was only marginally significant $(r=0.11 ; p=.06)$. The analysis of the correlation between subscales of the TEIP scale and teachers' attitudes toward inclusive education shows that there was a weak but significant relationship between Efficacy in Collaboration and attitudes toward inclusive education $(r=0.14 ; p<.05)$. There was, however, no significant relationship between Efficacy in Managing Behaviours $(r=0.06 ; p=.247)$ or Efficacy in Using Inclusive Instruction $(r=0.06 ; p=.251)$ and attitudes toward inclusive education. We also conducted a regression analysis with overall results of the TEIP scale and three factors of the TEIP scale as independent variables and the level of attitudes toward inclusive education as the dependent variable. In addition, we added teaching experience (in years) because that can be important for attitudes toward inclusion (Savolainen et al., 2012; Yada \& Savolainen, 2017). The results, however, were similar to those obtained in the correlations. The model for the entire TEIP scale, work experience, and attitudes toward inclusion was significant, $F(2,281)=5.15 ; p<.01$. However, self-efficacy was not a significant predictor of attitudes $(p=.154)$. Only work experience significantly predicted attitudes toward inclusion, as more experience predicted better attitudes $(\beta=0.165 ; p<.05)$. Overall, however, the model explained only $3.6 \%$ of the variance. The model with subscales of the TEIP scale and work experience was significant, $F(4,281)=3.097 ; p<.05$. However, Factor 1 (Efficacy in Managing Behaviours) and Factor 3 (Efficacy in Using Inclusive Instruction) were nonsignificant ( $p=1.0$ and $p=.60$, respectively). The only subscale that was marginally significant was Efficacy in Collaboration $(\beta=0.141 ; p=.07)$, as better efficacy predicted better attitudes. Also, work experience was significant in this model $(\beta=0.164 ; p<.01)$, as more experience predicted better attitudes. However, the second model explained only $4.3 \%$ of the overall variance.

\section{Discussion}

The main aim of the present study was to analyze the psychometric properties of the Polish version of the TEIP scale (Sharma et al., 2011), which measures the sense selfefficacy for teachers working in inclusive education setting. 


\section{Psychometric Properties of the TEIP Scale in the Polish Sample}

In our analysis, we were able to reproduce the three-factor structure that was shown by the authors of the original scale. This means that the scale allows for measuring not only a general sense of self-efficacy but also its dimensions such as efficacy in managing students' behaviours, efficacy in collaboration with professionals and parents, and efficacy in teaching in the inclusive classrooms in a sample of Polish teachers.

Obtaining a result similar to previous research makes it possible to compare the results from different studies. Polish teachers declared a high level of overall self-efficacy in inclusive education $(M=4.78 ; S D=0.60)$ similar to Finnish teachers $(M=4.53)$ and those from South Africa $(M=4.63$; Savolainen et al., 2012). A lower level of selfefficacy in inclusive education compared to Polish teachers was observed in a Japanese sample $(M=3.74$; Yada \& Savolainen, 2017). It is also worth mentioning that Polish teachers declared the highest self-efficacy in the subscale of using inclusive instruction. The same pattern of results was observed among Finnish and Japanese teachers (Savolainen et al., 2012; Yada \& Savolainen, 2017).

Park, Dimitrov, Das, \& Gichuru (2016) analyzed the construction of the TEIP scale with confirmatory factor analysis and showed that the scale has one dimension, meaning that it measures only one feature, the sense of self-efficacy in inclusive education. However, the scale also enables one to measure three specific latent factors distinguished by the authors of the scale: efficacy in inclusive teaching, collaboration, and managing difficult behaviours, which are specific aspects of the main feature of teachers' self-efficacy.

Analysis of reliability showed that Cronbach's $\alpha$ for the Polish version of the scale is high $(\alpha=0.93)$. The result is satisfactory and similar to other results obtained by the authors of the original scale $(\alpha=0.89)$; by Ahmmed, Sharma, $\&$ Deppeler (2014), who analyzed the results of teachers from Bangladesh $(\alpha=0.87)$; and by Sharma, Aiello, Pace, Round, \& Subban (2017), who conducted comparative analyses between Australian and Italian teachers $(\alpha=0.91$ and $\alpha=0.94$, respectively).

The sense of self-efficacy is a construct that is widely analyzed by international researchers (see Klassen et al., 2011), but not so much by Polish ones. There exists a Polish scale for studying general self-efficacy among teachers (Chomczyńska-Rubacha \& Rubacha, 2013), but we do not have a tool for measuring the sense of self-efficacy in inclusive settings. The sense of self-efficacy, according to Bandura (1971), is strongly connected with specific areas of functioning, which is why measurement and analysis of self-efficacy needs to be precise. The TEIP scale, in Polish adaptation, has allowed us to conduct a reliable study of self-efficacy in inclusive education. This will help us to identify the determinants of self-efficacy among teachers in inclusive education and will contribute to an understanding of the different effects of self-efficacy on the educational process.

Inclusive education is an important area of Polish educational policy, and it is continuously promulgated. Developing inclusive education is important not only for integration of people with disabilities but also for the development of the whole educational system (Szumski \& Karwowski, 2014; Smogorzewska, Szumski, \& Grygiel, 2019). That is why it is worthwhile to analyze different determinants of inclusive education effectiveness. One important role of teachers is to implement ideas of inclusion 
into educational practice. A higher sense of self-efficacy among teachers is important for better engagement in the educational process and for better results in students' learning. Teachers with high self-efficacy are also able to create a more welcoming climate in their classrooms (Allinder, 1994; Guo, McDonald Connor, Yang, Roehrig, \& Morrison, 2012; Herman et al., 2018).

\section{Relationship Between the TEIP Scale and Attitudes Toward Inclusive Education in a Polish Sample}

The sense of self-efficacy affects the thoughts, actions, and emotions of a person (Pervin \& John, 2004). The cognitive, behavioural, and affective spheres of people's functioning are components of attitudes, which people can have toward specific objects (Ajzen, 2001).The self-efficacy of a teacher translates to better engagement in work as well as confidence that a person is able to teach his or her students, including those with learning difficulties and disabilities. These premises were the basis for the assumption that there is a positive relationship between the sense of self-efficacy of teachers and their attitudes toward inclusive education. This assumption, however, was only partially supported. The correlation was observed only between the subscale of Efficacy in Collaboration and attitudes toward inclusive education $(r=0.14 ; p<.05)$. A similar relationship was previously observed in a study by Malinen et al. (2012), in which it was shown that Self-efficacy in Collaboration among teachers was the only factor that predicted attitudes toward inclusion. We obtained a similar result in our regression analysis. Savolainen et al. (2012) showed that Efficacy in Collaboration was not the only subscale, but was the strongest, to predict teachers' attitudes toward inclusive education. Additionally, we showed that work experience positively predicted attitudes toward inclusive education. In a study by Yada and Savolainen (2017) in Japan, work experience predicted attitudes toward inclusion, but negatively-more experience predicted worse attitudes. A similar relationship was found in a study by Savolainen et al. (2012), in which work experience negatively predicted attitudes toward inclusion. It is possible that older teachers in Poland did not have direct experience working with children with disabilities, so their positive attitudes are only declarative and not connected with real experience.

The lack of a statistically significant relationship between teachers' general sense of self-efficacy in inclusive education and their attitudes toward inclusive education is thought-provoking. Most previous studies on this topic have shown such a relationship (Meijer \& Foster, 1988; Miesera, DeVries, Jungjohann, \& Gebhardt, 2019; Özokcu, 2018; Savolainen et al., 2012; Weisel \& Dror, 2006; Yada \& Savolainen, 2017). Teachers with higher self-efficacy seem to have more positive attitudes toward including students with disabilities in mainstream schools, and at the same time, they show less concern about teaching in inclusive classrooms. Moreover, there are some results showing that the sense of self-efficacy predicts attitudes toward inclusive education, but there is a lack of longitudinal analyses (Malinen et al., 2012). However, not all research has shown a correlation between these variables. Kuyini, Desai, \& Sharma (2018) conducted a study among 134 primary school teachers in Ghana. Those teachers had doubts due to a lack of professional support, and they felt that their knowledge about teaching students with special educational needs was inadequate. They also displayed unfavourable attitudes toward inclusive education. Interestingly, the participants reported a high sense of self- 
efficacy in inclusive teaching. Thus, it is possible to notice a link between this study and the results of studies conducted among Polish teachers who assessed their situation in inclusive classrooms as difficult (Gajdzica, 2011). The teachers noticed a lack of proper support and insufficient knowledge in special education (Dajnowska \& Kosakowski, 2002). Overall, they felt uncertain in implementing inclusive assumptions in practice. It is probable that factors that are independent from teachers have a stronger impact on teachers' attitudes than personal self-efficacy. This explanation is supported by Özokcu (2018), who conducted a study with Turkish teachers. That study showed a positive relationship between the sense of self-efficacy in inclusive education and attitudes toward inclusion, but the sense of self-efficacy predicted only $8 \%$ of the variance in attitudes.

\section{Limitations}

Despite the satisfactory results of our study, which were sufficient to prepare a Polish adaptation of the TEIP scale, it is worth mentioning some weaknesses.

First, our sample was not huge $(N=291)$, and further analyses with larger samples are needed. Furthermore, our study was cross-sectional, so we were only able to run basic analyses such as correlation and regression with variables measured at the same time. Longitudinal analyses are still missing, and without them, it is impossible to observe the direction of the relationship between the sense of self-efficacy of teachers and their attitudes toward inclusive education.

The questionnaire, used for measuring attitudes toward inclusive education among teachers, could be used with other measures to observe its real validity. Although the questionnaire (prepared by Chow and Winzer, 1992) showed acceptable reliability in our sample $(\alpha=0.78)$, there are other measures that allow for more complex assessments of teachers' attitudes toward inclusive education such as the Sentiments, Attitudes, and Concerns About Inclusive Education Revised (SACIE-R) scale (Forlin, Earle, Loreman, \& Sharma, 2011). This questionnaire has already been used successfully by researchers who studied relationships between the sense of self-efficacy and attitudes toward inclusion (Malinen et al., 2012; Savolainen et al., 2012). Using this measure in our research would make it possible to compare the results of teachers' attitudes toward inclusion, which is otherwise impossible. However, this tool has not been adapted to Polish yet, which is why we used only Chow and Winzer's questionnaire. The adaptation of SACIE-R to Polish is one of our highest research priorities.

\section{Conclusion}

Although the TEIP scale (Sharma et al., 2011) has shown good psychometric properties in its Polish adaptation, the results of studies conducted on Polish samples (as well as several international studies) showing a positive correlation between the analyzed variables denote a need for further research with larger, more diverse, and representative samples. Moreover, it will be worthwhile to conduct longitudinal research that allows for different analyses of both constructs, which will help to better understand the relationship between them. It is also important to search for other factors that affect teachers' sense of self-efficacy in inclusive education. 
Narkun \& Smogorzewska

\section{References}

Ahmmed, M., Sharma, U., \& Deppeler, J. (2014). Variables affecting teachers' intentions to include students with disabilities in regular primary schools in Bangladesh. Disability \& Society, 29, 317-331. doi:10.1080/09687599.2013.796878

Ainscow, M., \& César, M. (2006). Inclusive education ten years after Salamanca: Setting the agenda. European Journal of Psychology of Education, 21, 231-238. doi:10.1007/BF03173412

Ajzen, I. (2001). Nature and operation of attitudes. Annual Review of Psychology, 52, 27-58. doi:10.1146/ annurev.psych.52.1.27

Allinder, R. M. (1994). The relationship between efficacy and the instructional practices of special education teachers and consultants. Teacher Education and Special Education, 17, 86-95. doi: $10.1177 / 088840649401700203$

Avramidis, E., Bayliss, P., \& Burden, R. (2000). A survey into mainstream teachers' attitudes towards the inclusion of children with special educational needs in the ordinary school one local education authority. Educational Psychology, 20, 191-211. doi:10.1080/713663717

Avramidis, E., \& Norwich, B. (2002). Teachers' attitudes towards integration/inclusion: A review of the literature. European Journal of Special Needs Education, 17, 129-147. doi:10.1080/08856250210129056

Bandura, A. (1971). Social learning theory. New York, NY: General Learning Press.

Bandura, A. (1977). Self-efficacy: Toward a unifying theory of behavioral change. Psychological Review, 84, 191-215. doi:10.1037/0033-295X.84.2.191

Caprara, G. V., Barbaranelli, C., Steca, P., \& Malone, P. S. (2006). Teachers' self-efficacy beliefs as determinants of job satisfaction and students' academic achievement: A study at the school level. Journal of School Psychology, 44, 473-490. doi:10.1016/j.jsp.2006.09.001

Central Statistical Office. (2007). Oświata i wychowanie w roku szkolnym 2006/2007 [Education in 2006/2007 school year]. Warszawa, Poland: Author.

Chomczyńska-Rubacha,M., \& Rubacha,K.(2013).Test poczucia skuteczności. Podręcznik pracowni narzędzi badawczych Komitetu Nauk Pedagogicznych PAN [The sense of efficiency test. Handbook of research tools. Laboratory of the Committee on Pedagogical Sciences of the Polish Academy of Sciences]. Torun, Poland: Wydawnictwo Naukowe UMK.

Chow, P., \& Winzer, M. (1992). Reliability and validity of a scale measuring attitudes toward mainstreaming. Educational and Psychological Measurement, 52, 223-228.

Chrzanowska, I. (2015). Pedagogika specjalna. Od tradycji do współczesności [Special education: From tradition to a present day] (pp. 532-581). Kraków, Poland: Oficyna Wydawnicza Impuls.

Coladarci, T. (1992). Teachers' sense of efficacy and commitment to teaching. Journal of Experimental Education, 60, 323-337.

Cousins, J. B., \& Walker, C. A. (2000). Predictors of educators' valuing of systematic inquiry in schools. Canadian Journal of Program Evaluation, Special Issue, 25-53.

Dajnowska, L., \& Kosakowski, Cz. (2002). Postawy nauczycieli szkół masowych w stosunku do osób upośledzonych umysłowo jako jeden z wyznaczników efektywności integracji [Mainstream teachers' attitudes toward people with intellectual disabilities as predictor of inclusive education effectiveness]. In M. Chodkowska (Ed.), Wielowymiarowość integracji w teorii $i$ praktyce edukacyjnej [Multidimensionality of inclusion in educational theory and practice] (pp. 43-58). Lublin, Poland: Wydawnictwo UMCS.

123 Exceptionality Education International, 2019, Vol. 29, No. 2 
de Boer, A., Pijl, J. S., \& Minnaert, A. (2011). Regular primary school teacher attitudes towards inclusive education: A review of the literature. International Journal of Inclusive Education, 15, 331-353. doi:10.1080/13603110903030089

De Neve, D., Devos, G., \& Tuytens, M. (2015). The importance of job resources and self-efficacy for beginning teachers' professional learning in differentiated instruction. Teacher and Teacher Education, 47, 30-41. doi:10.1016/j.tate.2014.12.003

The Education System Act. Journal of Laws of Republic of Poland, September 7, 1991, No. 95, item 425.

Forlin, C. (1995). Educators' beliefs about inclusive practices in Western Australia. British Journal of Special Education, 22, 179-185. doi:10.1080/0156655960430203

Forlin, C. (2010). Teacher education reform for enhancing teachers' preparedness for inclusion. International Journal of Inclusive Education, 14, 649-653. doi:10.1080/13603111003778353

Forlin, C., Earle, C., Loreman, T., \& Sharma, U. (2011) The Sentiments, Attitudes, and Concerns about Inclusive Education Revised (SACIE-R) scale for measuring pre-service teachers' perceptions about inclusion. Exceptionality Education International, 21, 50-65.

Gajdzica, Z. (2011). Sytuacje trudne w opinii nauczycieli klas integracyjnych. [Difficult situations in the opinion of teachers working in inclusive classrooms]. Kraków, Poland: Oficyna Wydawnicza Impuls.

Gibson, S., \& Dembo, M. (1984). Teacher efficacy: A construct validation. Journal of Educational Psychology, 76, 569-582. doi:10.1037/0022-0663.76.4.569

Guo, Y., McDonald Connor, C., Yang, Y., Roehrig, A. D., \& Morrison, F. J. (2012). The effects of teacher qualification, teacher self-efficacy, and classroom practices on fifth graders' literacy outcomes. Elementary School Journal, 113, 3-24. doi:10.1086/665816

Guo, Y., Piasta, B. S, Justice, M.L., \& Kaderavek, N. J. (2010). Relations among preschool teachers' self-efficacy, classroom quality, and children's language and literacy gains. Teacher and Teacher Education, 1094-1103. doi:10.1016/j.tate.2009.11.005.

Guskey, T. R., \& Passaro, P. D. (1994). Teacher efficacy: A study of construct dimensions. American Educational Research Journal, 31, 627-643. doi:10.2307/1163230

Herman, K., Hickmon-Rosa, J., \& Reinke M. W. (2018). Empirically derived profiles of teacher stress, burnout, self-efficacy and coping and student associated student outcomes. Journal of Positive Behavior Interventions, 20, 90-100. doi:10.1177/1098300717732066

Hoover-Dempsey, K., Bassler, O., \& Brissie, J. (1987). Parent involvement: Contributions of teacher efficacy, school socioeconomic status, and other school characteristics. American Educational Research Journal, 3, 417-435. doi:10.3102/00028312024003417

Kinsella, W., \& Senior, J. (2008). Developing inclusive schools: A systematic approach. International Journal of Inclusive Education, 12, 651-665. doi:10.1080/13603110802377698

Klassen, R. M., Tze, V. M. C., Betts, S. M., \& Gordon, K. A. (2011). Teacher efficacy research 19982009: Signs of progress or unfulfilled promise? Educational Psychology Review, 23, 21-43. doi:10.1007/s10648-010-9141-8

Klingner, J., Ahwee, S., Pilonieta, P.\& Menedez, R. (2003). Barriers and facilitators in scaling up research based practices. Exceptional Children 6, 411-429. doi:10.1177/001440290306900402

Kossewska, J. (2000). Uwarunkowania postaw: nauczyciele i inne grupy zawodowe wobec integracji spotecznej dzieci niepetnosprawnych. [Determinants of the attitudes: Teachers and other professional groups toward social integration of children with disability]. Kraków, Poland: Wydawnictwo Naukowe Akademii Pedagogicznej. 
Narkun \& Smogorzewska

Kuyini, B. A., Desai I., \& Sharma, U. (2018). Teachers' self-efficacy beliefs, attitudes and concerns about implementing inclusive education in Ghana. International Journal of Inclusive Education. Advance online publication. doi:10.1080/13603116.2018.1544298

Malinen, O. (2013). Inclusive education from teachers' perspective. Examining pre- and in-service teachers' self-efficacy and attitudes in mainland China. (Unpublished doctoral dissertation). University of Eastern Finland. Joensuu, Finland.

Malinen, O. , Savolainen, H., \& Xu, J. (2012). Beijing in-service teachers' self-efficacy and attitudes towards inclusive education. Teaching and Teacher Education, 28, 526-534. doi:10.1016/j.tate.2011.12.004

Meijer, C. J. W. (2003). Special needs education across Europe. Middelfart, Denmark: European Agency for Development in Special Needs Education.

Meijer, C. J. W., \& Foster, S. F. (1988). The effect of teacher self-efficacy on referral change. Journal of Special Education, 22, 378-385.

Miesera, S., DeVries, M. J., Jungjohann, J., \& Gebhardt, M. (2019). Correlation between attitudes, concerns, self-efficacy and teaching intentions in inclusive education evidence from German pre-service teachers using international scales. Journal of Research in Special Educational Needs, 19, 103-114. doi:10.1111/1471-3802.12432

Moberg, S., Muta, E., Korenaga, K., Kuorelahti, M., \& Savolainen H. (2019). Struggling for inclusive education in Japan and Finland: Teachers' attitudes towards inclusive education. European Journal of Special Needs Education. Advance online publication. doi:10.1080/08856257.2019.1615800

Özokcu, O. (2018). The relationship between teacher attitude and self-efficacy for inclusive practices in Turkey. Journal of Education and Training Studies, 6, 6-12. doi:10.11114/jets.v6i3.3034

Park, H.-M., Dimitrov, M. D., Das, A., \& Gichuru, M. (2016). The teacher efficacy for inclusive practice scale: dimensionality and factor structure. Journal of Research in Special Educational Needs, 16, 2-12. doi:10.1111/1471-3802.12047

Pervin, L. A., \& John, O. P. (2004). Personality: Theory and research. Hoboken, NJ: Wiley.

The Regulation of the Minister of National Education of the 9th of August 2017 on the conditions for the provision of education and care to children and young people who are disabled, socially maladjusted or at risk of social maladjustment. Journal of Law, item 1578 (changes: the 6th of August 2018, item 1485).

Riggs, I., \& Enochs, L. (1990). Toward the development of an elementary teacher's science teaching efficacy belief instrument. Science Education, 74, 625-638.

Ross, J. A., \& Bruce, C. (2007). Professional development effects on teacher efficacy: Results of randomized field trial. Journal of Educational Research, 101, 50-60. doi:10.3200/JOER.101.1.50-60

Savolainen, H., Engelbrecht, P., Nel, M., \& Malinen, O. (2012). Understanding teachers' attitudes and self-efficacy in inclusive education: Implications for pre-service and in-service teacher education. European Journal of Special Needs Education, 27, 51-68. doi:10.1080/08856257.2011.613603

Sharma, A., Aiello, P., Pace, E. M., Round, P., \& Subban, P. (2017). In-service teachers' attitudes, concerns, efficacy and intentions to teach in inclusive classrooms: An international comparison of Australian and Italian teachers. European Journal of Special Needs Education, 31, 458-471. doi:10.1080/08856257.2017.1361139 
Sharma, U., Loreman, T., \& Forlin, C. (2011). Measuring teacher efficacy to implement inclusive practices. Journal of Research in Special Educational Needs, 12, 12-21. doi:10.1111/j.14713802.2011.01200.x

Skaalvik, E. M., \& Skaalvik, S. (2007). Dimensions of teacher self-efficacy and relations with strain factors, perceived collective teacher efficacy and teacher burnout. Journal of Educational Psychology, 99, 611-625. doi:10.1037/0022-0663.99.3.611

Skaalvik, E. M., \& Skaalvik, S. (2010). Teacher self-efficacy and teacher burnout: A study of relations. Teacher and Teacher Education, 26, 1059-1069. doi:10.1016/j.tate.2009.11.001.

Smogorzewska, J., Szumski, G., \& Grygiel, P. (2019). Theory of mind development in school environment: A case of children with mild intellectual disability learning in inclusive and special education classrooms. Journal of Applied Research in Intellectual Disabilities.32, 1241-1254.doi:10.1111/jar.12616

Szumski, G. (2010). Wokół edukacji włączającej [Around inclusive education]. Warszawa, Poland: Wydawnictwo APS.

Szumski, G., \& Karwowski, M. (2014). Psychosocial functioning and school achievement of children with mild intellectual disability in Polish special, integrative, and mainstream schools. Journal of Policy and Practice in Intellectual Disabilities, 11, 99-108. doi:10.1111/jppi.12076

Tschannen-Moran, M., \& Woolfolk Hoy, A. (2007).The differential antecedents of self-efficacy beliefs of novice and experienced teachers. Teaching and Teacher Education, 23, 944-956. doi:10.1016/j.tate.2006.05.003

Tschannen-Moran, M., Woolfolk Hoy, A., \& Hoy, W. K. (1998). Teacher efficacy: Its meaning and measure. Review of Educational Research, 68, 202-248. doi:10.3102/00346543068002202

UNESCO. (1994). Salamanca statement and framework for action on special needs education. Paris, France: UNESCO.

Weisel, A., \& Dror, O. (2006). School climate, sense of efficacy and Israeli teachers' attitudes toward inclusion of students with special needs. Education, Citizenship and Social Justice,1, 157174. doi:10.1177/1746197906064677

Woolfolk Hoy, A., \& Burke Spero, R. (2005). Changes in teacher efficacy during the early years of teaching: A comparison of four measures. Teaching and Teacher Education, 21, 343-356. doi:10.1016/j.tate.2005.01.007

Yada, A., \& Savolainen, H. (2017). Japanese in-service teachers' attitudes towards inclusive education and self-efficacy for inclusive practices, Teaching and Teacher Education, 64, 222-229. doi:10.1016/j.tate.2017.02.005

\section{Authors' Note}

Correspondence concerning this article should be addressed to Zuzanna Narkun, The Maria Grzegorzewska University, Szczęśliwicka St., 40, 02353, Warsaw, Poland. Email: zuzanna.narkun@wp.pl 